\title{
Longitudinal Patterns in Sediment Type and Quality During Daily Flow Regimes and Following Natural Hazards In an Urban Estuary
}

\author{
Amin Kiaghadi ${ }^{1}$, Hanadi Rifai ${ }^{1},{\text { Mary } \text { Crum }^{1} \text {, and Richard Willson }}^{1}$ \\ ${ }^{1}$ University of Houston
}

October 12, 2020

\begin{abstract}
Understanding the transport of sediments in urban estuaries and their effects on water quality and microorganisms is a convergent challenge that has yet to be addressed especially as a result of natural hazards that affect the hydrodynamics of estuarine systems. This study provides a holistic view of the longitudinal nature and character of sediment in an urban estuary, the Galveston Bay Estuarine System (GBES), under daily and extreme flow regimes and presents the results of water and sediment sampling after Hurricane Harvey. The sediment sampling quantified total suspended sediment (TSS) concentrations, metal concentrations and the diversity of microbial communities. The results revealed the impact of the substantial sediment loads that were transported into the GBES in terms of the sediment grain type, the spatial distribution of trace metals and the diversity of microbial communities. A measurable shift in the percentage of silt relative to historical norms was noted in the GBES after Hurricane Harvey. Not only did sediment metal data confirm this shift and its ensuing impact on metal concentrations; microbial data provided ample evidence of the effect of leaks and spills from wastewater treatment plants, Superfund Sites and industrial runoff on microbial diversity. The research demonstrates the importance of understanding longitudinal sediment transport and deposition in estuarine systems under daily flow regimes, but more critically, following natural hazard events to ensure sustainability and resilience of systems such as the GBES that encounter numerous acute and chronic stresses.
\end{abstract}

\subsection{Introduction}

Sediments in urban estuaries have received much attention in the literature over the past few decades; they are well understood to be a critical component of estuarine ecosystems supporting biota and benthic organisms and microbial communities. Sediments also serve as a key environmental matrix in the form of a sink or source for chemicals and pollutants emanating from land areas surrounding the estuary. It is well established that sediments in estuarine systems are continuously changing over time due to the complex hydrodynamic interactions within the estuarine environment and human interventions that have altered natural flow patterns causing changes in freshwater inflows and sediment loads into estuaries.

While changes in sediment nature, character, and quality occur under daily flow regimes; they are amplified as a result of severe storms and hurricanes. In the case of hurricanes, especially when accompanied by storm surge, the elevated water velocities may mobilize the bed sediment moving it upstream and transporting and depositing it in other parts of the estuary. Alternations in salinity and $\mathrm{pH}$ during a hurricane (Kiaghadi \& Rifai, 2019), although for a limited amount of time, may also alter sediment quality and associated ecosystems (Ravisangaret al. , 2001; Carlin et al. , 2015). In the case of heavy rainfall accompanying hurricanes, such as was experienced during Harvey in the Houston-Galveston region, storm water runoff can cause significant shifts in the nature and character of sediment in estuarine environments ( $\mathrm{Du}$ et al. , 2019), the pollutants within them, and their microbial communities.

Research studies in the literature have reported on various aspects of sedimentation and erosion following natural hazards, however, none as of yet, have elucidated the observed longitudinal patterns in estuarine 
sediments in response to daily flow conditions and their response and recovery from a natural disaster such as Hurricane Harvey. Hurricane Harvey, a Category 4 storm that landed on August 25, 2017 on the coast of Texas has had a significant impact on the Galveston Bay Estuarine System (GBES)(NOAA National Centers for Environmental Information and (NCEI), 2018; Du et al. , 2019). The storm with its historic 50+ inches of rainfall, delivered more than $7,500 \mathrm{~km}^{3}$ of freshwater just from the Greater Houston watersheds, the Trinity River, and rainfall over the surface of the Houston Ship Channel-Galveston Bay (HSC-GB) water body; approximately 2.5 times the GBES volume. As a result, the GBES experienced its lowest salinities ever for an extended period of time after Harvey with associated adverse effects on its biota.

In addition to historic rainfall, an important consequence of Hurricane Harvey was the delivery of astounding amounts of sediment ( $9.86 \times 10^{7}$ metric tons) to the GBES (Du et al. , 2019). Houston's waterways, referred to as Rivers of Brown, were the main transport pathways for silts and sand into Galveston Bay and the Gulf of Mexico (Figure S1A and B in the Supplementary Information, SI). Sediment mobilization, polluted runoff, and spills and leaks during Harvey are thought to have caused acute and chronic changes in the physical, chemical and microbiological characteristics of water and sediment in Galveston Bay as reported in other estuaries after similar natural disasters (Sansalone et al. , 1998; SedNet, 2004; Stachel et al. , 2004; Pardue et al. , 2005; Hagy et al. , 2006; Mallin and Corbett, 2006; Adamset al. , 2007; Gong et al. , 2007; Amaral-Zettler et al. , 2008; Huang et al. , 2013; Horowitz et al. , 2014; Personna et al. , 2015; Reilly et al. , 2016; Romanoket al. , 2016; Mandigo et al. , 2016; Artigas et al. , 2017). It is noted, however, that while the type and grain size distribution of sediment and the changes in sediment pollutant concentrations have been well studied after natural disasters, few studies have focused on changes in microbial communities. Analyzing the microbial community within the sediment and water column may provide valuable information on ecosystem health (Cao et al. , 2006), especially since microbial communities exposed to environments enriched with complex toxics require several years to recover and return to their original composition (Bell et al. , 1990; Ahmann et al. , 1997; Ford et al. , 1998; Zhou et al. , 2002; Torsvik and Ovreas, 2002; Gillan, 2004; Branco et al. , 2005; Gillan et al. , 2005; Yannarell et al. , 2007; Allison and Martiny, 2008; Haller et al. , 2011; Zhao et al. , 2014; Yu et al. , 2018; Beattie et al. , 2018).

This paper takes a holistic look at sediment in the Galveston Bay Estuarine System (GBES), and presents historical Total Suspended Sediment (TSS), sediment grain size, trace metals, and flow data within the system; the data are used to characterize the longitudinal nature and character of sediment in the GBES under normal flow regimes. Uniquely, the paper presents sediment-sampling data collected after Hurricane Harvey including metals concentrations and diversity of microbial communities within the estuary and places the post-Harvey data in context relative to the historical dataset and relative to the recovery of the GBES from this natural disaster. The paper is novel because it answers the question of whether specific impacts of natural hazards can be effectively observed in sediment from natural water systems and whether sediment microbial communities can be used as indicators of system health in terms of exposure to increased pollutant loads from the estuarine watersheds due to increased sediment and associated pollutant loads. Importantly, the research presents a unique dataset of sediment analyses that were collected from deposited soil along the banks of two urban bayous, Brays Bayou and Buffalo Bayou, in Houston. The dataset is unique and illustrates the specific nature and character and pollutant entrainment within eroded sediment from watersheds that drain into the GBES.

\subsection{Methodology}

\subsection{Development of Flow, Sediment and Metals Historical Dataset}

Historical trace metal concentrations, TSS and grain size distribution data for sediments within the study area were acquired from the Texas Commission on Environmental Quality (TCEQ) Surface Water Quality Web Reporting Tool (TCEQ, 2020). WQM stations were selected based on data availability for the period from 1997 to 2017 for metals and 2000-2020 for TSS and sediment. Historical metals data were very limited; for sites with no data, upstream and downstream sites were used as an alternate. Flow data were collected from the United States Geological Survey (USGS) flow gages (https://waterdata.usgs.gov/nwis/rt) for the period of 1995-2020. 


\subsection{Sediment Sampling Post Harvey}

Six deposited soil samples (dried soil left after Hurricane Harvey due to overland deposition) from the banks of Brays Bayou, and five deposited soil samples from the banks of Buffalo Bayou were collected on October 6 and October 9, 2017, respectively (Figure 1T). Brays Bayou is the most urban bayou in Houston, whereas Buffalo Bayou is characterized by its Addicks and Barkers flood control reservoirs that reached capacity during Harvey and released water that exacerbated flooding and significantly affected water quality in the Bayou (Kiaghadi and Rifai, 2019). Most of the stations where deposited soil samples were collected were located in residential areas except station B6 (Figure 1T) that was located in a commercial area. The deposited soil samples were only tested for trace metals and not for Total Organic Carbon (TOC) and grain size due to the dominance of white sand and silt. In addition, no microbial analysis was conducted on deposited soil samples due to their exposed nature to wildlife.

Bed sediment samples in the tidal segments of the HSC-GB estuarine system (referred to as bed sediment samples for the remainder of the paper) were collected from 11 sampling sites (see Figure 1B) during the period from October 6 to October 27, 2017 (6-9 weeks after Hurricane Harvey landfall). The number of samples was determined based on prior knowledge of the HSC-GB while taking into account limitations in budget and sampling logistics. Most of the bayous and streams were back to a normal flow regime at the time of sampling with the exception of Buffalo Bayou. In addition to lower flow rates from the discharging bayous, satellite imagery (see Figure S1 in the SI) showed that sediment transport had largely abated at the time of sampling. Thus, all sediment samples were collected when the system had reached quasi-equilibrium in terms of sediment transport and deposition. The details of bed sediment and deposited sediment sampling and quality assurance are presented in the SI.

\subsection{Metals and Microbial Analyses}

Metals Analyses. All sediment and soil samples were tested for arsenic, cadmium, chromium, copper, lead, and nickel because of the presence of nearby Superfund sites that exhibit the six metals and the abundance of industries with discharge permits for these metals, located upstream and within the HSC-GB system. For metals, digestion and analysis followed EPA SW-846-6010D (U.S. EPA, 2014) ${ }^{8}$, and EPA 3050B (EPA, 1996), respectively (all of the analyses were conducted by an EPA accredited lab). All bed sediment samples were analyzed for TOC and grain size distribution within the 28-day limit for hold time following the Lloyd Kahns (Kahn, 1988) and ASTM D4464 (ASTM, 2015) standard methods, respectively. For all bed sediment sampling locations, field water quality parameters including $\mathrm{pH}, \mathrm{DO}$, and salinity for the bed layer (0.3 meters above the bottom of the waterbody) were measured using a field multi parameter water quality Sonde (600 XLM, YSI Inc.). Table S1 in the Supplementary Information (SI) provides a list of the sampled stations and their measured water quality parameters.

Trace metal concentrations in deposited soil samples were compared to protective concentration levels (PCLs) from the Texas Risk Reduction Program (TRRP) (TRRP, 2017) and regional screening levels (RSLs) for residential and commercial soils from the U.S.EPA (U.S. EPA, 2017) (see Table S2 in the SI). For bed sediments, combined PCLs (assuming metal intake is through all possible pathways) from TRRP for sediments were used (see Table S3 in the SI) in the comparison.

Microbial Analyses. Microbial genomic DNA was isolated from $250 \mathrm{mg}$ of sediments using DNeasy Powersoil kit from Qiagen(r) (Germantown, MD). Sequencing of the 16s rRNA v3, v4 and v5 region was completed in an accredited lab (Genewiz(r), New Jersey, USA) using the 16S MetaVx Environmental protocol on Illumina MiSeq with 2x250 bp configuration (the primer sequences used in the $16 \mathrm{~S}$ MetaVx environmental sequencing service are proprietary). Microbiome analyses were primarily carried out using a QIIME2 (Caporaso et al. , 2010) pipeline. The minimum nucleotide Phred quality score was set to 30; readings smaller or larger than 400 nucleotides were eliminated using Deblur plugins in QIIME2. Chimeric reads, including borderline sequences were removed via UCHIME (Edgar et al. , 2011). A total of approximately 10,074,932 reads were generated from the eleven samples. The Illumina sequence data have been deposited in the NCBI Sequence Read Archive under accession number PRJNA554335. 


\subsection{Comparison of Post-Harvey Sediment and Metal Concentrations to Historical Data}

The GBES was divided into three independent segments as shown in Figure S2 in the SI to account for the various hydrodynamic regimes; a riverine segment, a mid-bay segment, and a bottom-bay/outlet segment. All segments receive waters from Houston watersheds while Trinity Bay, East Bay, and West Bay (Figure S2 in the SI) were excluded from the analysis because they are affected by the Trinity River, the Intracoastal Waterway and Chocolate Bayou, respectively.

Sediment Grain Size and Transport Associated with Extreme Events. Data for several extreme events in the Houston area were used to elucidate observations related to changes in sediment and metals regimes after extreme events; the events included: Tropical Storm Allison (Allison, 2001), Hurricane Ike (Ike, 2008), Memorial Day Flood (MD, 2015), and Tax Day Flood (TD, 2016), and Hurricane Harvey (Harvey, 2017). Due to a lack of samples immediately before and after some of the events, samples collected one year before and after the events were used. The MD and TD floods occurred within a year of each other, thus for the purposes of the analysis in the paper, they were combined using a time period one year before MD to one year after TD flood. Similarly, the TD flood and Hurricane Harvey were combined, the data that was available between these two events was used as "after event" for TD flood and "before event" for Hurricane Harvey.

For each segment in the GBES shown in Figure S2 in the SI, average values of all existing data within the segment and before and after each event was used. The percent change in metal concentrations in sediment and changes in each grain type were calculated using:

$$
\text { Percent changes }(\%)=\frac{(\text { value prior to the event }- \text { value after the event })}{\text { value prior to the event }}
$$

The Pearson correlation test was performed on the percent change in metal concentrations and the percent change in each grain type. Arsenic and Cadmium were excluded from the correlation analysis because $46 \%$ and $58 \%$ of historical sediment samples showed values below the detection limit for arsenic and cadmium, respectively.

Additionally, and because of the unique volume of transported sediment during Harvey, additional analyses were undertaken for sediment data collected after Harvey that included visual inspection, repeated measures ANOVA (RM-ANOVA), and paired t-test statistical analyses using IBM ${ }^{\circledR}$ SPSS ${ }^{\circledR}$ (IBM, 2017) to place the data in context relative to historical patterns.

\subsection{Microbial Diversity Analysis}

Alpha and beta diversities reflect the richness within a sample and difference in bacterial composition among different sites, respectively (Morris et al. , 2014) . For alpha and beta diversity metrics, a rooted phylogenetic tree was generated and alpha rarefaction, as well as taxonomic classification of full-length sequences, was then performed using SILVA (Quast et al. , 2013). To standardize the data, only operational taxonomic units (OTUs) containing seven or more counts in at least one sample were retained prior to ordination in $\mathrm{R}$ using the Phyloseq package (McMurdie and Holmes, 2013). Approximately $75 \%$ of the original number of taxa across all samples was retained following the filtering criterion of including OTUs with 7 or more counts. The total number of OTUs following filtering and standardization was 5,776.

Principal Coordinates Analysis (PCoA) was used as the method of ordination that captured the most of total variance in the top 2 principal coordinates (mainly weighted UniFrac, a distance metric used to compare microbial communities), along with unweighted UniFrac for comparison (Lozupone and Knight, 2005). The UniFrac measure takes the phylogenetic relationship of species into account and is widely used in microbial ecology (Lozupone et al. , 2011). It should be noted that unweighted UniFrac is a qualitative measure of diversity mostly showing rare taxa, whereas the abundance of taxa is considered in weighted UniFrac, making it a quantitative measure (Lozupone et al. , 2007). While all OTUs were used to calculate diversity metrics 
and PCoA, microbial communities were investigated at the phylum level to find potential linkages between anthropogenic activities and the abundance of specific bacteria within each community.

Classic clustering using the unweighted pair group method with arithmetic mean (UPGMA), single linkage and Ward's methods, and K-means clustering at phylum level was conducted in PAST Package (Hammeret al. , 2001). For the K-means methods, three clusters were chosen based on some preliminary runs and considering channel samples, bay samples, and samples affected by the anthropogenic activities. The significance of the clustering analysis was tested using one-way multivariate analysis of variance (PERMANOVA). Stations were grouped based on the output of the clustering analysis and permutations ( $N=100,000$ due to the high number of variables) were used to assess significance.

\subsection{Effect of Environmental Factors on Metals and Microbial Communities}

Visual analysis and correlation analysis in SPSS ${ }^{\circledR}$ were undertaken to determine the correlation, if any, between the concentrations of different metals, microbial richness and diversity, bed water field water quality parameters, grain size and TOC levels. Moreover, a Principal Component Analysis (PCA) using environmental factors including water quality parameters, total water depth, grain size distribution, and TOC was performed to reduce the number of variables and observe any possible clustering behaviors based on measured environmental factors. To investigate the effect of environmental factors on microbial diversity, the results of UniFrac PCoA were compared with the developed environmental PCA to determine if there were supporting similarities between the two approaches.

In addition to the assumed linear response in PCA, and to consider unimodal species response to environmental factors, a canonical correspondence analysis (CCA) with log-transformation was performed using the environmental factors and microbial data at the phylum level. To consider the effect of trace metals, a separate CCA was conducted; only samples with measured metal data were considered due to the approach within the statistical software in treating missing data points (e.g., using the column average). Due to the limited number of samples for metals and multitude of environmental factors, the sum of all six measured metal concentrations was used as a single variable representing the metal effect, and the clay plus silt percentage was used to represent the sediment grain size effect. The Monte Carlo permutation test $(\mathrm{N}=5,000)$ was performed to test if the effect of environmental variables on the observed abundance of different phylum is significant. In other words, using such high number of $\mathrm{N}$ increases the likelihood of capturing random correlations. The CCA analysis and Monte Carlo permutation test were both performed in the PAST Package (Hammeret al. , 2001).

\section{Results and Discussion}

\subsection{Historical Sediment and Metals Concentrations}

Soil types in the Greater Houston Metropolitan Area (GHMA) are diverse (Figure S3-A in the SI). In general, the northern and northwestern parts of the GHMA are covered with sand, whereas the eastern and southern parts have more clay soil. Silt is the dominant grain type in areas closer to the main waterbodies and riverine/bayou system in the area. Almost all of the soils in the GHMA have a relatively high potential of erosion as shown in Figure S3-B in the SI. This high erosion potential combined with a history of flooding have led to significant loads of sediment into the GBES.

The data in Figure 2 illustrate flow exceedance rate curves in four of the major bayous in the GHMA for a 25-year period. The dots in Figure 2 represent the flow rates and their associated exceedance rates at the time when TSS samples were collected from the bayous over the years. As could be seen in the figure, the majority of the samples were collected when flow rates were low; an observation that is important because it highlights the lack of understanding of sediment loads associated with hurricanes and severe storms that disrupt the quasi-equilibrium that exists in sediment beds in natural water systems under normal flow regimes.

\subsection{Sediment Transport during Hurricane Harvey}

Sediment transport during Hurricane Harvey was mainly affected by the significant amount of silt carried 
by the floodwater from the highly erodible silt-rich soil behind Addicks Reservoir (flood control dam) and upstream of Greens Bayou (see Figure 1). TSS and flow data historically collected indicated that during the low to moderate flow regimes, there were significant correlations $(\mathrm{P}$-value $<0.05)$ between TSS concentrations and flow rates (at the time of sampling as) as shown in Figure S4 in the SI. During Hurricane Harvey, with the historical high flow rates, the measured TSS concentrations were higher than the median historical levels (see Figure 3 as an example). Using the median TSS values for each bayou multiplied by the daily flow rates from 1995 to 2020, Figure 4 shows the potential sediment daily load to the HSC-GB for each bayou. It should be noted that this figure does not show the outliers (mainly extreme events), and also, does not include all bayous/rivers discharging into the HSC-GB system due to the absence of flow gage or water quality monitoring stations in some of the tributaries. Even without the outliers, a load as high as 7,000 tons/day could have been discharged into the GBES just through the San Jacinto River (SJR).

\subsection{Grain Size Change during Hurricane Harvey}

Figure 5 shows the changes in grain type distribution in sediment samples collected before and after the five severe events in the studied segments. Among the studied storms, Hurricane Harvey showed completely different behavior compared to the other storms and will be discussed separately. Within the riverine segment of the system, the sand percentage increased while silt and clay percentages decreased during all events except Hurricane Harvey (Figure 5). For the same events, all metal concentrations (arsenic and cadmium were excluded) decreased in sediments collected from the riverine segment (Figure 6) suggesting a positive correlation between clay and silt percentage and trace metal concentrations. Within the Upper Bay segment, silt percentages decreased during TS Allison and MD+TD floods and increased during Hurricane Ike.

The opposite pattern was observed for sand. Changes in clay distribution were similar to silt except for a slight increase during TS Allison $(<10 \%)$. Metal concentrations in these sediments decreased during TS Allison and MD+TD floods (except lead during TS Allison) when silt and clay percentages decreased and metal concentrations increased during Hurricane Ike when silt and clay percentages increased. The Lower Bay/Outlet segment had a different sediment redistribution behavior compared to the other two segments during rain-based events; increasing in clay and silt and decreasing in sand percentages. Metal concentrations in the Lower Bay/Outlet decreased which is not consistent with the observed correlation between clay and silt percentages and metal concentrations in sediment. However, changes in clay plus silt distribution were only $+12 \%$ and changes in metal concentrations in sediments ranged from $-15 \%$ to $15 \%$ in the segment during TS Allison. Metal concentrations increased during the MD+TD floods as clay and silt percentages were increased. During a surge-based event, the Lower Bay/Outlet showed similar redistribution to the riverine and opposite to the Upper Bay segments. Higher silt and clay percentages after Hurricane Ike led to higher metal concentrations in Lower Bay/Outlet sediments.

As noted before, Hurricane Harvey had different behavior in grain type redistribution. Sediment transport during Hurricane Harvey was mainly affected by the tremendous amount of silt carried by the floodwater from an unknown source. Silt percentages in sediments became up to two times higher than samples collected before the event in all three of the segments. The effect was more significant in the Upper Bay (Figure 5). Within the riverine segment, the average concentration of all metals except copper increased compared to the average concentration of samples collected within a year before Hurricane Harvey.

Figure S5 (Top) in the SI shows the changes in grain size distribution for six stations from upstream to downstream that had grain size data collected between Harvey and the Tax Day flood event (April 2016) (grain size distribution for all 11 samples collected post-Harvey is shown in Figure S5 (Bottom) in the SI.). Silt and sand percentages in sediment were up to four times higher and nine times lower than samples collected less than a year before Harvey, respectively, while clay percentages did not change significantly. The t-tests showed similar results when the percentages of silt, sand, and clay were compared before and after Hurricane Harvey with P-values of $0.001,0.026$, and 0.437 , respectively. In addition, the results of RMANOVA showed that there was not a significant difference among samples collected before and after Harvey when considering all grain types and that there was no significant difference among grain types. However, when considering both factors (product of sampling event and grain type in IBM ${ }^{\circledR}$ SPSS ${ }^{\circledR}$ ), the difference 
was significant $(\mathrm{P}$-value $=0.048)$ indicating some of the grain types were significantly different before and after Harvey measurements. The observed changes in grain size distribution indicate the presence of newly introduced sediment to the system through the system boundary. These findings are consistent with other studies that reported on the effect of severe hydrological events on grain type distribution after Hurricane Sandy in New York and New Jersey (Reilly et al. , 2016; Romanok et al. , 2016; Artigaset al. , 2017) and after Hurricane Irene and Tropical Storm Lee on the east coast (Horowitz et al. , 2014).

\subsection{Trace Metals}

Trace Metals in Deposited Soil Samples. Figure 7 (A through D) shows the measured metal concentrations in the deposited soil collected from the banks of Buffalo and Brays Bayous (arsenic and cadmium were plotted as one group (Figure 7B and D) and the other four metals as another group to account for the different ranges in concentrations). No significant spatial trend in trace metal concentrations was found for the deposited soil in either of the two bayous. Measured metal concentrations were below both EPA's RSLs and TCEQ's PCLs except for arsenic. In four out of six Brays Bayou and two out of five Buffalo Bayou stations, arsenic levels were above EPA's RSLs and below TCEQ's PCL. One station with commercial land use (Brays Bayou at Broadway Street (B6), see Figure 1T), located at the confluence of Brays Bayou with the HSC, showed the highest concentrations of arsenic, cadmium, copper, and lead; such relatively high concentrations, however, might be attributed to construction activities that were observed during sampling. It is noteworthy that the most downstream sampled site (Buffalo Bayou at Sabine Rd (BB5), see Figure $1 \mathrm{~T}$ ), showed a significantly lower concentration of metals compared to upstream station BB4. This may be attributed to the unusally high and unexpected deposited amounts of sediment at BB5 (Figure S6 in the $\mathrm{SI})$.

Trace Metals in Bed Sediment Samples. Figures 7E and 7F show trace metal concentrations for the bed sediment samples; all were below PCLs. By comparing values shown in Figure 7 with historical data (Table S4 in the SI), it was found that cadmium levels in sediment measured after Hurricane Harvey were higher than historical levels in all stations although they were still below TCEQ's PCL. The highest levels of metals were observed in samples collected from the most western part of the HSC (station S1, Figure 1B). The observed values of cadmium, chromium, and nickel in station S1 were significantly higher than the values observed in deposited soils. This difference was attributed to the presence of Superfund sites and industrial activities near the western part of the channel. As shown in Figure S7 in the SI, between stations S1 and BB5, there are seven Superfund sites, five of which are still active (TCEQ, 2018); historically, metals contamination has been reported for these sites (U.S. EPA, 2018). During Harvey, leaks were reported from the U.S. Oil Recovery Superfund site located very close to the sampled station (NRC, 2017). Thus, the U.S. Oil Recovery Superfund site and local runoff from industrial areas surrounding the HSC might potentially be the source of high trace metals found in sediments collected from station S1.

\subsection{Microbial Communities in Bed Sediment Samples}

Alpha Diversity of Bacterial Communities. Alpha diversities defined by Shannon-Wiener and Simpson indices are shown in Figure 8. In general, an increasing trend in alpha diversity from station S1 to S4, all located in the western part of the HSC was observed followed by a decreasing trend from S5 to S10. Station S1 showed the lowest alpha diversity among all samples followed by stations S10, S9, and S6. As shown in Figure 1B, there are three active Superfund sites near station S9, three close to S10, one close to S1 (U.S. Oil Recovery), and one close to S6 (San Jacinto Waste Pits). The low alpha diversity of microbial communities observed at sampled sites close to the discharge points of Superfund sites might be attributed to the potential leaks and spills from the Superfund sites over the years, especially during severe events. Contrary to what might be expected, Station S5 that is very close to the San Jacinto Waste Pit Superfund site that exhibited failure in its cap during Hurricane Harvey (United States Coast Guard, 2020), showed higher diversity and number of OTUs compared to S6. This could be attributed to the specifics of the hydrodynamic regime at S5 that is located in the deeper part of the channel; the relatively high stream flow of the SJR (up to 10,200 $\mathrm{m}^{3} / \mathrm{s}$ ) during Harvey most likely washed out much of the sediment at this location. 
Beta Diversity of Bacterial Communities and Clustering. The unweighted UniFrac measure, coupled with PCoA displayed a pattern in the samples that seems to reflect the specificity of the sample physical location (Figure 9T). Axis 1 from the PCoA plot, accounted for $28.5 \%$ of the variation, grouped the S1/S2, S5/S6, S3/S4, S7/S8, and S9/S10/S11 stations together. As noted before, unweighted UniFrac mostly emphasizes the rare taxa, which could be affected by anthropogenic constituents found at these sites due to industrial and agricultural runoff or the presence of Superfund sites that could favor the proliferation of specific bacterial species and inhibit others. Stations S3, S4, S7, and S8 that are more distant from the Superfund site did not group with the ones that are near Superfund sites.

Stations S1 and S2, based on the diversity data, are influenced by the Superfund site and industrial activities adjacent to S1. Thermotogae, an anaerobic hyperthermophilic phylum commonly found in hydrocarbonimpacted sites (Nesbø et al. , 2010; Gupta and Bhandari, 2011), such as U.S. Oil Recovery Superfund site, was only found in station S1 (5.13\%), Latescibacteria, a saccharolytic and proteolytic phylum (Farag et al. , 2017), showed the highest richness in S1 (7.99\%), and Atribacteria, an anaerobic phylum usually found in marine sediments and petroleum reactors and reservoirs (Nobuet al. , 2016), was the most abundant in S1 $(9.37 \%)$ and S2 $(0.36 \%)$. At the genus level, Nitrosomonas were most abundant in the western part of the HSC system (1.27\% in S1) with high level of anthropogenic activities compared to Nitrospira that were most abundant in stations with the minimum level of anthropogenic activities ( $\mathrm{S} 5=2.55 \%, \mathrm{~S} 7=1.29 \%$ ) as observed in other studies (Cao et al. , 2006). Stations S5 and S6 were affected by potential leaks and spills from the San Jacinto Waste Pits, and the presence of grasslands and farms within the drainage area of the SJR that was the source of significant amounts of sediment transported into the HSC-GB system during Hurricane Harvey. Verrucomicrobia, a facultatively or obligately anaerobic phylum commonly found in grasslands (Janssen, 2006; Bergmannet al. , 2011) and in trace metals and nitrate-contaminated sites (Vishnivetskaya et al. , 2011), was most abundant in S6 (3.71\%) and S5 (2.17\%). In addition, Cyanobacteria, a photosynthetic and toxic phylum (Stanier et al., 1979; O'Neil et al. , 2012) commonly found in freshwater lakes (Jia et al. , 2017), were found in S5 (11.05\%) and S6 (7.72\%) at considerably higher levels than other stations. The source of Cyanobacteria could be from the freshwater that was released from Lake Houston, a constructed lake behind the Lake Houston dam, into the SJR at a rate of $10,000 \mathrm{~m}^{3} / \mathrm{s}$ during Hurricane Harvey. Five Superfund sites, spills and leaks from wastewater treatment plants as well as industrial runoff from various petrochemical industries located on the southwestern part of Galveston Bay potentially influence microbial diversity in S9 through S11. Ammonia-oxidizing phyla, commonly found in wastewater treatment plans (WWTPs) were the most abundant in stations S9 through S11. The highest abundance of Thaumarchaeota (Hatzenpichler, 2012) was found in S9 (1.94\%) and S10 (1.10\%) as well as the highest level of Phycisphaerae (Fuerst, 2017), which was found in abundance in S10 (2.85\%) and S9 (1.39\%). In addition, Chloroflexi (Mohamed et al. , 2010), found often in WWTPs (Kindaichi et al. , 2012), showed the highest sequences in S10 (5.67\%), S9 $(5.26 \%)$, and S11 (5.20\%).

The PCoA plot of the weighted Unifrac shows a different diversity pattern compared to the unweighted UniFrac (Figure 9A and B). Axis 1 from weighted Unifrac PCoA accounted for the highest variation of 65.6\%. As shown in Figure 9B, weighted Unifrac grouped samples into three groups. Group 1 consisted of sample S1, group 2 comprised S11 and S10, and group 3 included the rest of the samples. Proteobacteria followed by Bacteroidetes were the most abundant phyla of bacteria in all samples and together accounted for more than $70 \%$ of OTUs in all samples except for station S1 (63.45\%). The observed range of abundance for Proteobacteria in bed sediment samples (35.10\%-67.34\%) was within the reported range in the literature (22.95\%-64\%) (Spain et al. , 2009; Kormas et al. , 2010; Vishnivetskaya et al. , 2011; Bowen et al. , 2012; Sun et al. , 2013; Zhu et al. , 2013; Hieke et al. , 2016). However, Bacteroidetes showed higher abundance in bed sediment samples (11.21\%-32.70\%) compared to the reported values in the literature (1.9\%-14.42\%) (Spain et al. , 2009; Vishnivetskaya et al., 2011; Bowen et al., 2012; Sun et al. , 2013; Zhu et al. , 2013; Hieke et al. , 2016). Higher levels of Bacteroidetes, up to 50\%, were only observed in anaerobic digesters (Chen et al. , 2016) and the high measured range of this phylum in almost all bed sediment samples may be indicative of the effect of spills and leaks from wastewater treatment plants during Hurricane Harvey. This is an important finding since Bacteroidetes have been linked to human metabolic diseases (Johnsonet al. , 
2017) that could potentially increase the risk of exposure to both water and sediment.

The results of the clustering analysis for all classical methods and K-mean clustering test (K=3) showed similar outputs. The output clusters were 1) stations S1, S5, and S6, all located close to Superfund sites with reported leaks during Hurricane Harvey, 2) S2, S3, S4, and S8, all located in the deeper part of the HSC, and 3) all other stations located in the open and shallow bays (S7, S9, S10, and S11). Here again, the effects of geometry (the specificity of the sample physical location) and the presence of hazardous sites were confirmed. PERMANOVA results using the three clusters showed P-values smaller than 0.01 that indicates the rejection of null hypothesis; the phylum distribution and abundances among the clusters are not equal.

\subsection{Environmental Factors}

Effects on Trace Metal Concentrations. For all metals except arsenic, a significant and strong correlation between metal concentrations and TOC concentrations was found (P-values< 0.008) (Table S5 in the SI). TOC levels, as would be expected, showed a strong negative correlation $(\mathrm{R}=-0.69, \mathrm{P}$-value $=0.028)$ with the sand percentage in bed sediment samples.

Effects on Microbial Communities. Correlation analysis showed no significant correlation among bed water quality parameters and alpha diversity indices. However, the results did show significant and negative correlations $(\mathrm{R}>0.73, \mathrm{P}$-values $<0.038)$ among trace metal concentrations and the Simpson index. For the Shannon-Wiener index, all metals except arsenic and cadmium showed significant correlations. Copper, chromium, nickel, and lead concentrations at station S1 were identified as influential points.

The groups in the weighted Unifrac (Figure 4B) showed some similarities to the PCA plot developed using field water quality parameters, and grain size distributions as shown in Figure 9C. The PCA1 shown in the $\mathrm{x}$-axis of Figure $4 \mathrm{C}$ accounted for $42.85 \%$ of variation in the dataset and was dominated by the level of sand, clay, silt, and TOC. The sampling stations were grouped into S1, S10, S2/S5/S6/S11, and S3/S4/S7/S8/S9. The similarities in groups between the weighted Unifrac and environmental PCAs (see Figure 9) and the fact that the $\mathrm{x}$-axis in environmental PCA is describing sediment distribution may suggest that unlike rare bacteria, the distribution of common bacteria in samples could be a function of sediment composition in the system.

Figure 10 shows the results of the CCA for both scenarios described in Section 2.6, one with all environmental factors except metals and the other one with reduced size environmental factors including metals. For both scenarios, the results were very similar to the PCoA plot of the weighted Unifrac (Figure 4B). Extremophile phylum (rare) could be found on the right side of the CCA figures (Figure 5) with the closest station being S1. Among environmental factors, metals and TOC had the closest distance to S1, indicating the potential effect of both organic and inorganic pollutants on the microbial communities at S1. Station S7 through S11 all located in the side bays and Galveston Bay (see Figure 1B for locations) showed the shortest distance to salinity, DO, and pH while stations S1 through S5 located in the western and deeper parts of the system showed more proximity to total depth and sediment grain size variables. The permutation test for both scenarios showed P-values greater than 0.05 meaning failing to reject the null hypothesis that the observed correlation among the environmental factors and microbial diversities was due to chance. Overall, the lack of a significant correlation among metal concentrations and the field water parameters at the bed layer and among environmental factors and microbial diversities could be an indication that the system has not reached equilibrium in terms of chemical and microbial properties and partitioning among phases.

\subsection{Conclusions}

A significant amount of sediment transport from the upstream watersheds occurred during Harvey in the GBES that significantly altered the nature and character of bed sediment relative to historical data. Qualitative and quantitative analyses conducted in the study provided strong evidence of the effect of this alteration on the metal distributions and the microbial community characteristics of the HSC-GB sediments. The difference in metal concentrations in sediment samples collected from the tidal part of the estuarine system compared to ones in deposited soil samples collected from the banks of freshwater bayous was indicative of 
associations to potential leaks from nearby active Superfund sites and entrainment of pollutants in industrial runoff. Locations with realtively high levels of toxic metals and nearby reported spills and leaks during Hurricane Harvey showed significant different diversity and richness in microbial communities (at the phylum level). Additionally, the relatively high abundance of ammonia-oxidizers and extremophile bacteria in samples confirms the importance of polluted sediment transport, caused by anthropogenic activities, from urban and rural areas into the estuarine system during Hurricane Harvey. Thus, it can be concluded that natural hazards change bed sediments in various ways and have a lasting impact on estuarine environments long after the event has passed. Quantifying sediment physical, chemical, and biological characteristics after natural hazards is critical towards understansing the long term sustainability and resilience of these important coastal environments.

\subsection{Supporting Information (SI)}

Bed Sediment Sampling. Deposited Soil sampling. Quality Assurance for Sediment Sampling.

List of WQM stations with their studied parameters (Table S1), Criteria for trace metals in soils (mg/kg) (Table S2), PCLs for trace metals in sediment samples $(\mathrm{mg} / \mathrm{kg}$ ) (Table S3), Maximum and most recent historical trace metal concentrations in sampled sediment sites (Table S4), Total depth, sediment total organic carbon (TOC), and field water quality parameters measured at the bed layer of waterbodies (Table S5).

Muddy waters in Rivers of Brown, Galveston Bay, and Gulf Mexico in the aftermath of Hurricane Harvey. (A) On August 31, 2017, 6 days after Hurricane Harvey's landfall. Photo captured by Moderate Resolution Imaging Spectroradiometer (MODIS) on NASA's Terra satellite. (B) through (D) are Sentinel 2, Level2A: Bottom of atmosphere reflectance, true color photos from 9/1/17, 10/1/17, and 10/11/17, respectively (Figure S1), HSC-GB system segmentation (Figure S2), Spatial distribution of A) soil type, and B) erosion potential in the Greater Houston metropolitan (Figure S3), TSS concentrations plotted against the flow rates at the time of sampling for four of the major bayous in the GHMA (Figure S4), Grain type distribution in sediment samples collected from the tidal segments of the HSC-GB system post Hurricane Harvey for different stations (Figure S5), Deposited soil along Buffalo Bayou in Buffalo Bayou Park (29.764, -95.384) close to BB5 (see Figure 1 in the manuscript) Photos taken on 09/17/2017 (Figure S6), Location of deposited soil sampling stations and tidal sampling location relative to nearby Superfund sites (Figure S7).

\subsection{Acknowledgements}

NSF RAPID Grant \# 1759440 funded this research; their support is gratefully acknowledged. Daniel Burleson, Rose Sobel, Emily Sappington, Aparna Balasubramani, Adithya Govindarajan, Jacob Furrh, and Maria Modelska are acknowledged for their help with sample collection and analysis, photography and for providing valuable comments on the manuscript.

\subsection{Data Availability}

The microbial diversity data that support the findings of this study are openly available from the NCBI Sequence Read Archive under accession number PRJNA554335.

\subsection{References}

Adams, C., Witt, E. C., Wang, J. M., Shaver, D. K., Summers, D., Filali-Meknassi, Y., Shi, H. L., Luna, R., \& Anderson, N. (2007). Chemical Quality of Depositional Sediments and Associated Soils in New Orleans and the Louisiana Peninsula Following Hurricane Katrina.Environmental Science 8 Technology , 41 (10), 3437-3443. doi:10.1021/es0620991

Ahmann, D., Krumholz, L. R., Hemond, H. F., Lovley, D. R., \& Morel, F. M. M. (1997). Microbial Mobilization of Arsenic from Sediments of the Aberjona Watershed. Environmental Science 83 Technology ,31 (10), 2923-2930.

Allison, S. D., \& Martiny, J. B. H. (2008). Resistance, Resilience, and Redundancy in Microbial 
Communities. Proceedings of the National Academy of Sciences, 105 (Supplement 1), 11512-11519. doi:10.1073/pnas.0801925105

Amaral-Zettler, L. A., Rocca, J. D., Lamontagne, M. G., Dennett, M. R., \& Gast, R. J. (2008). Changes in Microbial Community Structure in the Wake of Hurricanes Katrina and Rita. Environmental Science 83 Technology , 42 (24), 9072-9078. doi:10.1021/es801904z

Artigas, F., Loh, J. M., Shin, J. Y., Grzyb, J., \& Yao, Y. (2017). Baseline and Distribution of Organic Pollutants and Heavy Metals in Tidal Creek Sediments after Hurricane Sandy in the Meadowlands of New Jersey. Environmental Earth Sciences , 76 (7). doi:10.1007/s12665-017-6604-y

ASTM D4464-15. (2015). "Standard Test Method for Particle Size Distribution of Catalytic Materials by Laser Light Scattering ", ASTM International, West Conshohocken, PA, www.astm.org.

Beattie, R. E., Henke, W., Campa, M. F., Hazen, T. C., McAliley, L. R., \& Campbell, J. H. (2018). Variation in microbial community structure correlates with heavy-metal contamination in soils decades after mining ceased. Soil Biology and Biochemistry , 126 , 57-63. doi:https://doi.org/10.1016/j.soilbio.2018.08.011

Bell, P. E., Herlihy, A. T., \& Mills, A. L. (1990). Establishment of anaerobic, reducing conditions in lake sediment after deposition of acidic, aerobic sediment by a major storm.Biogeochemistry , 9 , (2), 99-116. doi: 10.1007/BF00692167

Bergmann, G. T., Bates, S. T., Eilers, K. G., Lauber, C. L., Caporaso, J. G., Walters, W. A., Knight, R., \& Fierer, N., The Under-Recognized Dominance of Verrucomicrobia in Soil Bacterial Communities. Soil Biology 83 Biochemistry , 43 (7), 1450-1455. doi: 10.1016/j.soilbio.2011.03.012

Blake, E. S., \& Zelinsky, D. A., Tropical Cyclone Report: Hurricane Harvey. National Hurricane Center, U.S. Department of Commerce(Accessed January 2018).

Bowen, J. L., Morrison, H. G., Hobbie, J. E., \& Sogin, M. L. (2012). Salt Marsh Sediment Diversity: A Test Of The Variability of The Rare Biosphere Among Environmental Replicates. The Isme Journal , 6 , 2014-2023. doi:10.1038/ismej.2012.47

Branco, R., Chung, A.-P., Veríssimo, A., \& Morais, P. V. (2005). Impact of chromium-contaminated wastewaters on the microbial community of a river. FEMS Microbiology Ecology , 54 (1), 35-46. doi:10.1016/j.femsec.2005.02.014

Cao, Y., Cherr, G. N., Córdova-Kreylos, A. L., Fan, T. W. M., Green, P. G., Higashi, R. M., LaMontagne, M. G., Scow, K. M., Vines, C. A., Yuan, J., Holden, P. A. (2006). Relationships between Sediment Microbial Communities and Pollutants in Two California Salt Marshes.Microbial Ecology , 52(4), 619-633. doi:10.1007/s00248-006-9093-1

Caporaso, J. G., Kuczynski, J., Stombaugh, J., Bittinger, K., Bushman, F. D., Costello, E. K., Fierer, N., Peña, A. G., Goodrich, J. K., Gordon, J. I., Huttley, G. A., Kelley, S. T., Knights, D., Koenig, J. E., Ley, R. E., Lozupone, C. A., McDonald, D., Muegge, B. D., Pirrung, M., Reeder, J., Sevinsky, J. R., Turnbaugh, P. J., Walters, W. A., Widmann, J., Yatsunenko, T., Zaneveld, J., \& Knight, R. (2010). QIIME Allows Analysis of High-Throughput Community Sequencing Data.Nature Methods , 7 , 335.

Chen, S., Cheng, H., Wyckoff, K. N., \& He, Q. (2016). Linkages of Firmicutes and Bacteroidetes Populations to Methanogenic Process Performance. Journal of Industrial Microbiology $\&$ Biotechnology , 43 (6), 771-781. doi: 10.1007/s10295-016-1760-8

Du, J., Park, K., Dellapenna, T. M., \& Clay, J. M. (2019). Dramatic hydrodynamic and sedimentary responses in Galveston Bay and adjacent inner shelf to Hurricane Harvey. Science of the Total Environment, 2019. 653: p. 554-564. doi:10.1016/j.scitotenv.2018.10.403

EPA. (2017). Regional Screening Levels (RSLs) - Generic Tables. United States Environmental Protection Agancy; Available from: https://www.epa.gov/risk/regional-screening-levels-rsls-generic-tables, (Acces- 
sed September 2018).

Edgar, R. C., Haas, B. J., Clemente, J. C., Quince, C., \& Knight, R. (2011). UCHIME Improves Sensitivity and Speed of Chimera Detection.Bioinformatics , 27 (16), 2194-2200. doi:10.1093/bioinformatics/btr381

Farag, I. F., Youssef, N. H., \& Elshahed, M. S. (2017) Global Distribution Patterns and Pangenomic Diversity of the Candidate Phylum "Latescibacteria" (WS3). Applied and Environmental Microbiology , 83 (10). doi: 10.1128/AEM.00521-17

Ford, T., Sorci, J., Ika, R., \& Shine, J. (1998). Interactions between metals and microbial communities in New Bedford Harbor, Massachusetts.Environmental Health Perspectives , 106 , 1033-1039. doi:10.2307/3434148

Fuerst, J. (2017). Chapter 1. Planctomycetes-New Models for Microbial Cells and Activities . Microbial Resources from Functional Existence in Nature to Applications. pp. 1-27

Gillan, D. C. (2004). The Effect of an Acute Copper Exposure on the Diversity of a Microbial Community in North Sea Sediments as Revealed by DGGE Analysis-the Importance of the Protocol. Marine Pollution Bulletin , 49 (5), 504-513. doi:https://doi.org/10.1016/j.marpolbul.2004.03.003

Gillan, D. C., Danis, B., Pernet, P., Joly, G., \& Dubois, P. (2005). Structure of Sediment-Associated Microbial Communities along a Heavy-Metal Contamination Gradient in the Marine Environment.Applied and Environmental Microbiology , 71 (2), 679-690. doi:10.1128/AEM.71.2.679-690.2005

Gong, W. P., Shen, J., \& Reay, W. G. (2007). The hydrodynamic response of the York River Estuary to Tropical Cyclone Isabel, 2003.Estuarine Coastal and Shelf Science , 73 (3-4), 695-710. doi:10.1016/j.ecss.2007.03.012

Gupta, R. S., \& Bhandari, V. (2011). Phylogeny and Molecular Signatures for the Phylum Thermotogae and its Subgroups. Antonie Van Leeuwenhoek International Journal of General and Molecular Microbiology , 100 (1), 1-34. doi: 10.1007/s10482-011-9576-z

Hagy, J. D., Lehrter, J. C., \& Murrell, M. C. (2006). Effects of Hurricane Ivan on Water Quality in Pensacola Bay, Florida.Estuaries and Coasts, 29 (6A), 919-925.

Haller, L., Tonolla, M., Zopfi, J., Peduzzi, R., Wildi, W., \& Pote, J. (2011). Composition of Bacterial and Archaeal Communities in Freshwater Sediments with Different Contamination Levels (Lake Geneva, Switzerland). Water research , 45, (3), 1213-1228. doi: 10.1016/j.watres.2010.11.018

Hammer, O., Harper, D., \& Ryan, P. (2001). PAST: Paleontological Statistics Software Package for Education and Data Analysis.Palaeontologia Electronica, 4 , 1-9

Hatzenpichler, R. (2012). Diversity, Physiology, and Niche Differentiation of Ammonia-Oxidizing Archaea. Applied and Environmental Microbiology , 78 (21), 7501-7510. doi:10.1128/AEM.01960-12

Hieke, A.-S., Brinkmeyer, R., Yeager, K., Schindler, K., Zhang, S., Xu, C., Louchouarn, P., \& Santschi, P. (2016). Widespread distribution of Dehalococcoides mccartyi in the Houston Ship Channel and Galveston Bay, Texas, sediments and the potential for reductive Dechlorination of PCDD/F in an estuarine environment ., Vol. 18, pp. 630-644.

Horowitz, A. J., Elrick, K. A., Smith, J. J., Stephens, V. C. (2014). The Effects of Hurricane Irene and Tropical Storm Lee on the Bed Sediment Geochemistry of US Atlantic Coastal Rivers. Hydrological Processes , 28 (3), 1250-1259. doi:10.1002/hyp.9635

Huang, W. R., Hagen, S., \& Bacopoulos, P. (2014). Hydrodynamic Modeling of Hurricane Dennis Impact on Estuarine Salinity Variation in Apalachicola Bay. Journal of Coastal Research , 30(2), 389-398. doi:10.2112/jcoastres-d-13-00022.1

IBM. (2017). IBM SPSS Statistics for Windows, Version 25.0 ; IBM Corp: Armonk, NY. 
Janssen, P. H. (2006). Identifying the Dominant Soil Bacterial Taxa in Libraries of 16S Rrna And 16S Rrna Genes. Applied and Environmental Microbiology , 72 (3), 1719-1728. doi: 10.1128/AEM.72.3.1719-1728.2006

Jia, J. M., Shi, W. Q., Chen, Q. W., \& Lauridsen, T. L. (2017). Spatial and Temporal Variations Reveal the Response of Zooplankton to Cyanobacteria. Harmful Algae , 64 , 63-73. doi: 10.1016/j.hal.2017.02.008

Johnson, E. L., Heaver, S. L., Walters, W. A., \& Ley, R. E. (2017). Microbiome and Metabolic Disease: Revisiting the Bacterial Phylum Bacteroidetes. Journal of Molecular Medicine , 95(1), 1-8. doi:10.1007/s00109016-1492-2

Kahn, L. (1988). "Determination of Total Organic Carbon in Sediment", USEPA, Region II, July 27, https://www.nj.gov/dep/srp/guidance/rs/lloydkahn.pdf.

Kindaichi, T., Yuri, S., Ozaki, N., \& Ohashi, A. (2012). Ecophysiological Role and Function of Uncultured Chloroflexi on an Anammox Reactor. Water Science and Technology , 66(12), 2556-2561. doi: 10.2166/wst.2012.479

Kapoor, V., Gupta, I., Pasha, A. B. M. T., \& Phan, D. (2018). Real-Time Quantitative PCR Measurements of Fecal Indicator Bacteria and Human-Associated Source Tracking Markers in a Texas River Following Hurricane Harvey. Environmental Science 83 Technology Letters , 5 (6), 322-328.

Kiaghadi, A., \& Rifai, H. S. (2019). Physical, Chemical, and Microbial Quality of Floodwaters in Houston Following Hurricane Harvey.Environmental Science 86 Technology , 53(9), 4832-4840. doi:10.1021/acs.est.9b00792.

Kormas, K. A., Vardaka, E., Moustaka-Gouni, M., Kontoyanni, V., Petridou, E., Gkelis, S., \& Neofitou, C. (2010). Molecular Detection of Potentially Toxic Cyanobacteria and Their Associated Bacteria in Lake Water Column and Sediment. World Journal of Microbiology and Biotechnology , 26 (8), 1473-1482. doi: 10.1007/s11274-010-0322-x

Lozupone, C., \& Knight, R. (2005). UniFrac: a New Phylogenetic Method for Comparing Microbial Communities. Applied and environmental microbiology , 71 (12), 8228-8235.

Lozupone, C., Lladser, M. E., Knights, D., Stombaugh, J., \& Knight, R. (2011). Unifrac: An Effective Distance Metric for Microbial Community Comparison. The ISME journal , 5 (2), 169. doi: 10.1038/ismej.2010.133

Lozupone, C. A., Hamady, M., Kelley, S. T., \& Knight, R. (2007). Quantitative and Qualitative $\beta$ Diversity Measures Lead to Different Insights into Factors that Structure Microbial Communities. Applied and environmental microbiology , 73 (5), 1576-1585. doi: 10.1128/AEM.01996-06

Mallin, M. A., \& Corbett, C. A. (2006). How Hurricane Attributes Determine the Extent of Environmental Effects: Multiple Hurricanes and Different Coastal Systems. Estuaries and Coasts ,29 (6), 1046-1061.

McMurdie, P. J., \&Holmes, S. (2013). Phyloseq: An R Package for Reproducible Interactive Analysis and Graphics of Microbiome Census Data. Plos One , 8 (4). Doi:10.1371/journal.pone.0061217

Mandigo, A. C., DiScenza, D. J., Keimowitz, A. R., \& Fitzgerald, N. (2016). Chemical Contamination of Soils in the New York City Area Following Hurricane Sandy. Environmental Geochemistry and Health , 38 (5), 1115-1124. doi:10.1007/s10653-015-9776-y

Mohamed, N. M., Saito, K., Tal, Y., \& Hill, R. T. (2009). Diversity of Aerobic And Anaerobic AmmoniaOxidizing Bacteria in Marine Sponges. The Isme Journal , 4 , 38. doi: 10.1038/ismej.2009.84

Morris, E. K., Caruso, T., Buscot, F., Fischer, M., Hancock, C., Maier, T. S., Meiners, T., Müller, C., Obermaier, E., \& Prati, D. (2014). Choosing and Using Diversity Indices: Insights for Ecological Applications from the German Biodiversity Exploratories. Ecology and evolution , 4 (18), 3514-3524. doi: 10.1002/ece3.1155

NCEI Billion-Dollar Weather and Climate Disasters, National Centers for Environmental Information (NCEI),https://www.ncdc.noaa.gov/billions/events/US/1980-2017(Accessed January 2018). 
Nesbo, C. L., Kumaraswamy, R., Dlutek, M., Doolittle, W. F., \& Foght, J. (2010). Searching for Mesophilic Thermotogales Bacteria: "Mesotogas" in the Wild. Applied and Environmental Microbiology ,76 (14), 48964900. doi: 10.1128/AEM.02846-09

Nobu, M. K., Dodsworth, J. A., Murugapiran, S. K., Rinke, C., Gies, E. A., Webster, G., Schwientek, P., Kille, P., Parkes, R. J., Sass, H., Jorgensen, B. B., Weightman, A. J., Liu, W. T., Hallam, S. J., Tsiamis, G., Woyke, T., \& Hedlund, B. P. (2016). Phylogeny and Physiology of Candidate Phylum 'Atribacteria' (OP9/JS1) Inferred from Cultivation-Independent Genomics. Isme Journal ,10 (2), 273-286. doi: 10.1038/ismej.2015.97

NRC. (2017). National Response Center (NRC)'s Incident Reporting Information System (IRIS) Report.http://www80.tceq.texas.gov/SwqmisPublic/(Accessed February 2018).

O'Neil, J. M., Davis, T. W., Burford, M. A., \& Gobler, C. J. (2012). The Rise of Harmful Cyanobacteria Blooms: the Potential Roles of Eutrophication and Climate Change. Harmful Algae ,14 , 313-334. doi: 10.1016/j.hal.2011.10.027

Pardue, J. H., Moe, W. M., McInnis, D., Thibodeaux, L. J., Valsaraj, K. T., Maciasz, E., van Heerden, I., Korevec, N., \& Yuan, Q. Z. (2005). Chemical and microbiological parameters in New Orleans floodwater following Hurricane Katrina. Environmental Science $\&$ Technology , 39 (22), 8591-8599. doi:10.1021/es0518631

Personna, Y. R., Geng, X., Saleh, F., Shu, Z., Jackson, N., Weinstein, M. P., \& Boufadel, M. C. (2015). Monitoring changes in salinity and metal concentrations in New Jersey (USA) Coastal Ecosystems PostHurricane Sandy. Environmental Earth Sciences ,73 (3), 1169-1177. doi:10.1007/s12665-014-3539-4

Quast, C., Pruesse, E., Yilmaz, P., Gerken, J., Schweer, T., Yarza, P., Peplies, J., \& Glöckner, F. O. (2013). The SILVA Ribosomal RNA Gene Database Project: Improved Data Processing And Web-Based Tools.Nucleic acids research , 41 (Database issue), D590-D596. doi: 10.1093/nar/gks1219

Reilly, T. J., Focazio, M. J., \& Simmons, D. L. (2016). Resetting the bar: Establishing Baselines for Persistent Contaminants after Hurricane Sandy in the Coastal Environments of New Jersey and New York, USA.Marine Pollution Bulletin , 107 (2), 414-421. doi:10.1016/j.marpolbul.2016.05.045

Rippka, R., Deruelles, J., Waterbury, J. B., Herdman, M., \& Stanier, R. Y. (1979). Generic Assignments, Strain Histories and Properties of Pure Cultures of Cyanobacteria. Journal of General Microbiology , 111 (MAR), 1-61. doi: 10.1099/00221287-111-1-1

Romanok, K. M., Szabo, Z., Reilly, T. J., Defne, Z., \& Ganju, N. K. (2016). Sediment Chemistry and Toxicity in Barnegat Bay, New Jersey: Pre- and Post-Hurricane Sandy, 2012-13. Marine Pollution Bulletin , 107 (2), 472-488. doi:10.1016/j.marpolbul.2016.04.018

SedNet. (2004). Contaminated sediments in European river basins ; European Sediment Research Network: Netherlands, p 69. https://sednet.org/wp-content/uploads/2016/03/Sednet_booklet_final_2.pdf

Spain, A. M., Krumholz, L. R., \& Elshahed, M. S. (2009). Abundance, Composition, Diversity and Novelty of Soil Proteobacteria. The Isme Journal , 3 , 992. doi: 10.1038/ismej.2009.43

Stachel, B., Gotz, R., Herrmann, T., Kruger, F., Knoth, W., Papke, O., Rauhut, U., Reincke, H., Schwartz, R., Steeg, E., \& Uhlig, S. (2004). The Elbe Flood in August 2002 - Occurrence of Polychlorinated DibenzoP-Dioxins, Polychlorinated Dibenzofurans (PCDD/F) and Dioxin-Like Pcb in Suspended Particulate Matter (SPM), Sediment and Fish. Water Science and Technology , 50 (5), 309-316.

Sansalone, J. J., Koran, J. M., Smithson, J. A., \& Buchberger, S. G. (1998). Physical Characteristics of Urban Roadway Solids Transported During Rain Events. Journal of Environmental Engineering-ASCE , 124 (5), 427-440. doi:10.1061/(asce)0733-9372(1998)124:5(427)

Sun, M. Y., Dafforn, K. A., Johnston, E. L., \& Brown, M. V. (2013). Core Sediment Bacteria Drive Community Response to Anthropogenic Contamination Over Multiple Environmental Gradients. Environmental Microbiology , 15 (9), 2517-2531. doi: 10.1111/1462-2920.12133 
TCEQ. Surface Water Quality Web Reporting Tool. Available from: http://www80.tceq.texas.gov/SwqmisPublic/, (Accessed March 2018).

TCEQ. (2018). TCEQ Superfund Sites by County. https://www.tceq.texas.gov/remediation/superfund/sites/county, (Accessed September 2018).

Torsvik, V., \& Øvreås, L. (2002). Microbial Diversity and Function in Soil: From Genes to Ecosystems. Current opinion in microbiology , 5 (3), 240-245. https://doi.org/10.1016/S1369-5274(02)00324-7

TRRP. Texas Risk Reduction Program Protective Concentration Levels . 2017; Available from: https://www.tceq.texas.gov/remediation/trrp/trrppcls.html, (Accessed September 2018).

U.S. EPA. (2014). "Method 6010D (SW-846): Inductively Coupled Plasma-Atomic Emission Spectrometry ," Revision 4. Washington, DC.

U.S. EPA. (1996). "Method 3050B: Acid Digestion of Sediments, Sludges, and Soils ," Revision 2. Washington, DC.

U. S. EPA. (2018). U. S. EPA's Superfund Program, https://www.epa.gov/superfund, (Accessed September 2018).

Vishnivetskaya, T. A., Mosher, J. J., Palumbo, A. V., Yang, Z. K., Podar, M., Brown, S. D., Brooks, S. C., Gu, B., Southworth, G. R., Drake, M. M., Brandt, C. C., \& Elias, D. A. (2011). Mercury and Other Heavy Metals Influence Bacterial Community Structure in Contaminated Tennessee Streams. Applied and Environmental Microbiology , 77 (1), 302-311. doi: 10.1128/AEM.01715-10

Yannarell, A. C., Steppe, T. F., \& Paerl, H. W. (2007). Disturbance and Recovery of Microbial Community Structure and Function Following Hurricane Frances. Environ Microbiol , 9 , (3), 576-583. doi: 10.1111/j.1462-2920.2006.01173.x

Yu, P., Zaleski, A., Li, Q., He, Y., Mapili, K., Pruden, A., Alvarez, P. J. J. \& Stadler, L. B(2018). Elevated Levels of Pathogenic Indicator Bacteria and Antibiotic Resistance Genes after Hurricane Harvey's Flooding in Houston. Environmental Science $\&$ Technology Letters , 5 (8), 481-486. doi:10.1021/acs.estlett.8b00329

Zhao, Y.-G., Feng, G., Bai, J., Chen, M., \& Maqbool, F. (2014). Effect of copper exposure on bacterial community structure and function in the sediments of Jiaozhou Bay, China. World Journal of Microbiology Es Biotechnology , 30 (7), 2033-2043. doi:10.1007/s11274-014-1628-x

Zhou, J., Xia, B., Treves, D. S., Wu, L. Y., Marsh, T. L., O'Neill,, R. V., Palumbo, A. V., \& Tiedje, J. M. (2002). Spatial and Resource Factors Influencing High Microbial Diversity in Soil. Applied and Environmental Microbiology , 68 (1), 326-334.

Zhu, D. C., Tanabe, S. H., Yang, C., Zhang, W. M., \& Sun, J. Z. (2013). Bacterial Community Composition of South China Sea Sediments through Pyrosequencing-Based Analysis of 16S rRNA Genes. Plos One , 8 (10). doi: 10.1371/journal.pone.0078501

\section{Hosted file}

Figure Captions.pdf available at https://authorea.com/users/366166/articles/485962longitudinal-patterns-in-sediment-type-and-quality-during-daily-flow-regimes-andfollowing-natural-hazards-in-an-urban-estuary

\section{Hosted file}

Figure 1 wCap.pdf available at https://authorea.com/users/366166/articles/485962longitudinal-patterns-in-sediment-type-and-quality-during-daily-flow-regimes-andfollowing-natural-hazards-in-an-urban-estuary

\section{Hosted file}


Figure 2 wCap.pdf available at https://authorea.com/users/366166/articles/485962longitudinal-patterns-in-sediment-type-and-quality-during-daily-flow-regimes-andfollowing-natural-hazards-in-an-urban-estuary

\section{Hosted file}

Figure 3 wCap.pdf available at https://authorea.com/users/366166/articles/485962longitudinal-patterns-in-sediment-type-and-quality-during-daily-flow-regimes-andfollowing-natural-hazards-in-an-urban-estuary

\section{Hosted file}

Figure 4 wCap.pdf available at https://authorea.com/users/366166/articles/485962longitudinal-patterns-in-sediment-type-and-quality-during-daily-flow-regimes-andfollowing-natural-hazards-in-an-urban-estuary

\section{Hosted file}

Figure 5 wCap.pdf available at https://authorea.com/users/366166/articles/485962longitudinal-patterns-in-sediment-type-and-quality-during-daily-flow-regimes-andfollowing-natural-hazards-in-an-urban-estuary

\section{Hosted file}

Figure 6 wCap.pdf available at https://authorea.com/users/366166/articles/485962longitudinal-patterns-in-sediment-type-and-quality-during-daily-flow-regimes-andfollowing-natural-hazards-in-an-urban-estuary

\section{Hosted file}

Figure 7 wCap.pdf available at https://authorea.com/users/366166/articles/485962longitudinal-patterns-in-sediment-type-and-quality-during-daily-flow-regimes-andfollowing-natural-hazards-in-an-urban-estuary

\section{Hosted file}

Figure 8 wCap.pdf available at https://authorea.com/users/366166/articles/485962longitudinal-patterns-in-sediment-type-and-quality-during-daily-flow-regimes-andfollowing-natural-hazards-in-an-urban-estuary

\section{Hosted file}

Figure 9 wCap.pdf available at https://authorea.com/users/366166/articles/485962longitudinal-patterns-in-sediment-type-and-quality-during-daily-flow-regimes-andfollowing-natural-hazards-in-an-urban-estuary

\section{Hosted file}

Figure 10 wCap.pdf available at https://authorea.com/users/366166/articles/485962longitudinal-patterns-in-sediment-type-and-quality-during-daily-flow-regimes-andfollowing-natural-hazards-in-an-urban-estuary 